\title{
Characterization of Bacillus brevis with Descriptions of Bacillus migulanus sp. nov., Bacillus choshinensis sp. nov., Bacillus parabrevis sp. nov., and Bacillus galactophilus sp. nov.

\author{
HIROAKI TAKAGI, ${ }^{1 *}$ OSAMU SHIDA, ${ }^{1}$ KIYOSHI KADOWAKI, ${ }^{1}$ KAZUO KOMAGATA, ${ }^{2}$
} AND SHIGEZO UDAKA ${ }^{3}$
}

Research Laboratory, Higeta Shoyu Co., Ltd., Choshi, Chiba $288,{ }^{1}$ Department of Agricultural Chemistry, Faculty of Agriculture, Tokyo University of Agriculture, Setagaya-ku, Tokyo $156,{ }^{2}$ and Department of Food Science and Technology, Faculty of Agriculture, Nagoya University, Chikusa-ku, Nagoya 464, ${ }^{3}$ Japan

\begin{abstract}
Thirty-five Bacillus brevis strains obtained from culture collections, including protein-producing isolates, were taxonomically studied by using numerical analysis, DNA base composition, and DNA-DNA hybridization. Six DNA relatedness groups were represented, and these groups correlated well with clusters based on the numerical analysis. The $B$. brevis strains were separated into $B$. brevis sensu stricto, four new species, and an unidentified species of the genus Bacillus. Bacillus migulanus sp. nov., Bacillus choshinensis sp. nov., Bacillus parabrevis sp. nov., and Bacillus galactophilus sp. nov. are proposed.
\end{abstract}

The heterogeneity of Bacillus brevis has been indicated by the wide range of maximum growth temperatures (10) and the results of numerical classification $(13,26,27)$ and classification based on API test data (17). The protein producers identified as $B$. brevis (45) had guanine-plus-cytosine $(\mathrm{G}+\mathrm{C})$ contents ranging from 47 to 55 mol\%. These observations suggest that this taxon is genetically heterogeneous. Recently, Nakamura (23) reported that the phenotypic heterogeneity of $B$. brevis was due to variability introduced by the presence of genetically unrelated strains. Previously, Udaka (44) and Takagi et al. (37) reported the bacterial production of large amounts of proteins in culture fluids; many of the bacteria involved appeared phenotypically to be $B$. brevis $(37,44)$. These strains showed either weak or no detectable proteolytic activity in the culture supernatant (37). B. brevis 47 and HPD31 have been employed successfully as host bacteria for extracellular production of foreign proteins, such as bacterial thermophilic $\alpha$-amylase (38) and human epidermal growth factor (49). Additional unique characteristics of $B$. brevis that have been reported are gramicidin production (9) and molluscicidal activity (31).

In order to clarify the taxonomic positions of $14 \mathrm{~B}$. brevis strains from culture collections and of 21 protein-producing isolates, we examined their phenotypic characteristics and processed the data obtained by using standard numerical analysis. In addition, the relationships between clusters resulting from the numerical analysis were evaluated by DNA-DNA hybridization.

As a result, the above-mentioned 35 strains assigned to $B$. brevis were divided into six independent species, four of which are proposed below as the new species Bacillus migulanus, Bacillus choshinensis, Bacillus parabrevis, and Bacillus galactophilus.

\section{MATERIALS AND METHODS}

Bacterial strains. B. brevis strains and reference strains obtained from culture collections and other sources and the protein-producing strains described previously $(37,44)$ were

\footnotetext{
* Corresponding author.
}

used in this study. The sources and histories of these strains are listed in Table 1 . Working stocks were cultivated on T2 agar (44) for $24 \mathrm{~h}$ at 30 or $37^{\circ} \mathrm{C}$ and were stored at a room temperature.

Characterization. Unless indicated otherwise, the methods described by Gordon et al. (10) were used for characterization of organisms. Acid production from carbohydrates was determined for $\mathrm{D}$-glucose, L-arabinose, D-fructose, D-galactose, D-xylose, maltose, lactose, sucrose, trehalose, glycerol, D-mannitol, and starch. The methods described by Komagata (14) were used for hydrolysis of urea, Tween 60 , and Tween 80; utilization of nitrate, ammonium, and citrate; the oxidase reaction; fermentation of glucose; and production of hydrogen sulfide. Hydrolysis of DNA was determined by using Bacto DNase test agar (Difco Laboratories, Detroit, Mich.). Resistance to antibiotics was determined by growth on T2 agar supplemented with antibiotics (Table 2). Growth inhibition by the strains tested was investigated by using Escherichia coli $\mathrm{JCM} 1649^{\mathrm{T}}$ ( $\mathrm{T}=$ type strain) and Bacillus subtilis JCM $1465^{\mathrm{T}}$.

Chromosomal DNA preparation. Chromosomal DNAs were isolated from bacterial cells cultured overnight in T2 medium at 30 or $37^{\circ} \mathrm{C}$ by the method of Saito and Miura (30). The prepared DNA had $A_{235} / A_{260}$ and $A_{280} / A_{260}$ ratios of less than 0.55 .

DNA base composition. DNA base composition was determined by the method of Tamaoka and Komagata (39), with some modifications. DNAs were heated at $100^{\circ} \mathrm{C}$ for $10 \mathrm{~min}$ and hydrolyzed with $4 \mathrm{U}$ of nuclease P1 (Yamasa Shoyu Co., Chiba, Japan) per $\mathrm{ml}$ at $50^{\circ} \mathrm{C}$ for $2 \mathrm{~h}$. After treatment with bacterial phosphatase (Takara Shuzo Co., Kyoto, Japan), the samples were analyzed by high-performance liquid chromatography with an apparatus equipped with a Microbondasphere $\mathrm{C}_{18}$ column (3.9 by $150 \mathrm{~mm}$; Waters, Nihon Millipore Ltd., Tokyo, Japan). Deoxyribonucleosides were eluted with a mobile phase consisting of $200 \mathrm{mM} \mathrm{NH}_{4} \mathrm{H}_{2} \mathrm{PO}_{4}(\mathrm{pH}$ 4.0) supplemented with $2.5 \%$ acetonitrile.

Numerical analysis. Phenetic relationships among the strains tested were determined by a cluster analysis, using 57 differential characteristics (Table 2). Similarity among strains was estimated by using the simple matching coeffi- 


\begin{tabular}{|c|c|c|c|}
\hline \multicolumn{2}{|r|}{ Strain } & \multirow{2}{*}{ Source $^{b}$} & \multirow{2}{*}{ History } \\
\hline Laboratory no. & Designation $^{a}$ & & \\
\hline \multicolumn{4}{|l|}{ B. brevis strains } \\
\hline 1 & ATCC $9999^{\mathrm{T}}$ & ATCC & $\begin{array}{l}\text { NCTC } 7096 \text { from R. Synge from Moscow, USSR, gramicidin S- } \\
\text { producing strain }\end{array}$ \\
\hline 2 & NRRL NRS-606 & NRRL & J. R. Porter from G. Bredemann \\
\hline 3 & HP926 & Our isolate & Isolated from soil \\
\hline 4 & HPD31 & Our isolate & H. Takagi et al., protein-producing strain \\
\hline 5 & HPD $52^{\mathrm{T}}$ & Our isolate & H. Takagi et al., protein-producing strain \\
\hline 6 & HP1501 & Our isolate & H. Takagi et al., protein-producing strain \\
\hline 7 & 444 & Our isolate & S. Udaka, protein-producing strain \\
\hline 8 & $\mathrm{JCM} 2503^{\mathrm{T}}$ & JCM & $\begin{array}{l}\text { DSM } 30 \text { from ATCC } 8246 \text { from N. R. Smith strain } 604 \text { from J. R. } \\
\text { Porter from NCTC } 2611 \text { from W. W. Ford strain } 27 B\end{array}$ \\
\hline 9 & NRRL NRS-614 & NRRL & J. R. Porter from G. Bredemann \\
\hline 10 & ATCC 11031 & ATCC & N. R. Smith strain 799 from C. Lamanna strain B4 \\
\hline 11 & 481 & Our isolate & S. Udaka, protein-producing strain \\
\hline 12 & ATCC 35690 & ATCC & Z. Kurylo-Borowska strain Vm4, edein A- and B-producing strain \\
\hline 13 & 47 & Our isolate & S. Udaka, protein-producing strain $(=\mathrm{JCM} 6285)$ \\
\hline 14 & 144 & Our isolate & S. Udaka, protein-producing strain \\
\hline 15 & 899 & Our isolate & S. Udaka, protein-producing strain \\
\hline 16 & NRRL NRS-1212 & NRRL & H. W. Reuszer Army strain 1133 \\
\hline 17 & HP033 & Our isolate & H. Takagi et al., protein-producing strain \\
\hline 18 & HP026 & Our isolate & H. Takagi et al., protein-producing strain \\
\hline 19 & HP1201 & Our isolate & H. Takagi et al., protein-producing strain \\
\hline 20 & ATCC 8185 & ATCC & $\begin{array}{l}\text { N. R. Smith strain } 751 \text { from R. J. Dubos strain BG, gramicidin- } \\
\text { producing strain }\end{array}$ \\
\hline 21 & IFO $12334^{\mathrm{T}}$ & IFO & $\begin{array}{l}\text { ATCC } 10027 \text { from N. R. Smith strain } 605 \text { from J. R. Porter from } \\
\text { G. Bredemann }\end{array}$ \\
\hline 22 & IFO 12374 & IFO & $\begin{array}{l}\text { CCM } 1463 \text { from NCIB } 7577 \text { from NCTC } 7577 \text { from T. Gibson } \\
\text { strain } 108\end{array}$ \\
\hline 23 & NRRL NRS- $616^{\mathrm{T}}$ & NRRL & J. R. Porter from G. Bredemann \\
\hline 24 & HP1301 & Our isolate & H. Takagi et al., protein-producing strain \\
\hline 25 & IFO 12333 & IFO & ATCC 8186 from R. J. Dubos strain OKA \\
\hline 26 & IFO 12335 & IFO & ATCC 10068 from WRRL, gramicidin-producing strain \\
\hline 27 & HP030 & Our isolate & H. Takagi et al., protein-producing strain \\
\hline 28 & HP1304 & Our isolate & H. Takagi et al., protein-producing strain \\
\hline 29 & HP032 & Our isolate & H. Takagi et al., protein-producing strain \\
\hline 30 & HP1302 & Our isolate & H. Takagi et al., protein-producing strain \\
\hline 31 & HP601 & Our isolate & H. Takagi et al., protein-producing strain \\
\hline 32 & HP602 & Our isolate & H. Takagi et al., protein-producing strain \\
\hline 33 & HP603 & Our isolate & H. Takagi et al., protein-producing strain \\
\hline 34 & HP1502 & Our isolate & H. Takagi et al., protein-producing strain \\
\hline 35 & HP037 & Our isolate & H. Takagi et al., protein-producing strain \\
\hline \multicolumn{4}{|l|}{ Other Bacillus } \\
\hline 36 & B. subtilis JCM $1465^{\mathrm{T}}$ & $\mathrm{JCM}$ & IAM 12118 from ATCC 6051 from H. J. Cohn Marburg strain \\
\hline 37 & B. sphaericus JCM $2502^{\mathrm{T}}$ & $\mathrm{JCM}$ & CCM 2120 from R. E. Gordon \\
\hline 38 & B. laterosporus JCM $2496^{\mathrm{T}}$ & JCM & CCM 2116 from R. E. Gordon \\
\hline 39 & B. licheniformis $\mathrm{JCM} 2505^{\mathrm{T}}$ & $\mathrm{JCM}$ & CCM 2145 from R. E. Gordon \\
\hline 40 & B. coagulans $\mathrm{JCM} 2257^{\mathrm{T}}$ & $\mathrm{JCM}$ & $\begin{array}{l}\text { IAM } 1115 \text { from ATCC } 7050 \text { from N. R. Smith strain } 609 \text { from } \\
\text { J. R. Porter from W. Hammer }\end{array}$ \\
\hline 41 & B. macerans $\mathrm{JCM} 2500^{\mathrm{T}}$ & JCM & CCM 2012 from R. E. Gordon \\
\hline 42 & "B. aneurinolyticus" АТCC 11376 & ATCC & K. Arima, thiaminase-producing strain \\
\hline 43 & "B. aneurinolyticus" ATCC 12856 & ATCC & Y. Ito from R. Kimura (= IAM 1077) \\
\hline 44 & B. alvei IFO $3343^{\mathrm{T}}$ & IFO & $\begin{array}{l}\text { IMAB B-3-4 from ATCC } 6344 \text { from N. R. Smith strain } 662 \text { from } \\
\text { A. G. Lochhead strain } 127\end{array}$ \\
\hline 45 & B. badius ATCC $14574^{\mathrm{T}}$ & ATCC & $\begin{array}{l}\text { R. E. Gordon from N. R. Smith strain } 663 \text { from Henry strain } 110 \\
\text { from M. Batchelor }\end{array}$ \\
\hline 46 & "B. freudenreichii" ATCC 7053 & ATCC & N. R. Smith strain 671 from T. Gordon strain 68 \\
\hline 47 & B. thiaminolyticus JCM 7538 & $\mathrm{JCM}$ & R. Azuma strain 461 from cattle (= NIAH 1025$)$ \\
\hline 48 & B. thiaminolyticus JCM 7539 & JCM & Osaka University Medical School (= IFO 3115) \\
\hline 49 & B. thiaminolyticus JCM 7540 & JCM & K. Arima (= IFO 1034) \\
\hline 50 & B. thiaminolyticus JCM $8360^{\mathrm{T}}$ & $\mathrm{JCM}$ & AHU 1393 \\
\hline
\end{tabular}

${ }^{a}$ Names in quotation marks are not on the Approved Lists of Bacterial Names (32) or in the Index of the Bacterial and Yeast Nomenclatural Changes (20) and had not been validly published as of 1 April 1992.

${ }^{b}$ ATCC, American Type Culture Collection, Rockville, Md.; NRRL, Microbial Properties Research, National Center for Agricultural Utilization Research, Peoria, Ill.; JCM, Japan Collection of Microorganisms, Saitama, Japan; IFO, Institute for Fermentation, Osaka, Osaka, Japan.

c NCTC, National Collection of Type Cultures, Central Public Health Laboratory Service, London, United Kingdom; DSM, Deutsche Sammlung von Mikroorganismen, Braunschweig, Germany; CCM, Czechoslovak Collection of Microorganisms, Masaryk University, Brno, Czechoslovakia; NCIB, National Collection of Industrial Bacteria, NCIMB Ltd., Aberdeen, Scotland, United Kingdom; IAM, Institute of Applied Microbiology, University of Tokyo, Tokyo, Japan; WRRL, Western Utilization Research and Development Division, U.S. Department of Agriculture, Albany, Calif.; NIAH, National Institute of Animal Health, Ibaraki, Japan; AHU, Department of Agricultural Chemistry, Hokkaido University, Hokkaido, Japan. 
TABLE 2. Phenotypic characteristics of $B$. brevis and the new species

\begin{tabular}{|c|c|c|c|c|c|c|}
\hline Characteristic & $\begin{array}{l}\text { B. migulanus } \\
\text { (DNA group } \\
\text { A; } n=2)^{a}\end{array}$ & $\begin{array}{c}\begin{array}{c}\text { DNA group B } \\
(n=1)\end{array} \\
\end{array}$ & $\begin{array}{c}\text { B. choshinensis } \\
\text { (DNA group C; } \\
n=2 \text { ) }\end{array}$ & $\begin{array}{l}B, \text { brevis } \\
\text { (DNA } \\
\text { group D; } \\
n=14 \text { ) }\end{array}$ & $\begin{array}{l}\text { B. parabrevis } \\
\text { (DNA group } \\
\text { E; } n=14 \text { ) }\end{array}$ & $\begin{array}{c}\text { B. galactophilus } \\
\text { (DNA group F; } \\
\quad n=2 \text { ) }\end{array}$ \\
\hline Cell width of $>0.5 \mu \mathrm{m}$ & $100^{b}$ & 100 & 100 & 71 & 79 & 50 \\
\hline Cell length of $>3.0 \mu \mathrm{m}$ & 100 & 100 & 100 & 79 & 50 & 50 \\
\hline Sporangia swollen & 100 & 100 & 100 & 100 & 100 & 100 \\
\hline Spherical spores & 0 & 0 & 0 & 0 & 0 & 0 \\
\hline Spore position terminal & 100 & 100 & 100 & 93 & 100 & 100 \\
\hline Colonies pale yellow & 100 & 100 & 100 & 71 & 50 & 100 \\
\hline Gram positive & 100 & 100 & 100 & 93 & 88 & 50 \\
\hline Anaerobic growth & 0 & 0 & 0 & 0 & 0 & 0 \\
\hline Catalase & 100 & 100 & 100 & 100 & 100 & 100 \\
\hline Oxidase & 100 & 100 & 100 & 93 & 93 & 50 \\
\hline Nitrate reduction & 100 & 100 & 0 & 79 & 100 & 0 \\
\hline Voges-Proskauer reaction & 0 & 0 & 0 & 0 & 0 & 0 \\
\hline $\begin{array}{l}\text { pH of Voges-Proskauer broth } \\
\text { of }>7.0\end{array}$ & 100 & 100 & 100 & 100 & 100 & 100 \\
\hline \multicolumn{7}{|l|}{ Utilization of: } \\
\hline Citrate (Koser) & 0 & 100 & 100 & 64 & 29 & 0 \\
\hline Citrate (Christensen) & 0 & 0 & 100 & 79 & 79 & 50 \\
\hline Nitrate & 0 & 0 & 0 & 0 & 0 & 0 \\
\hline Ammonium & 100 & 100 & 100 & 86 & 100 & 100 \\
\hline \multicolumn{7}{|l|}{ Hydrolysis of: } \\
\hline Casein & 0 & 0 & 0 & 100 & 100 & 100 \\
\hline Gelatin & 0 & 0 & 0 & 100 & 100 & 100 \\
\hline DNA & 100 & 0 & 50 & 100 & 100 & 100 \\
\hline Starch & 0 & 0 & 0 & 0 & 0 & 0 \\
\hline Tween 60 & 0 & 0 & 0 & 100 & 100 & 100 \\
\hline Tween 80 & 0 & 0 & 0 & 71 & 93 & 100 \\
\hline Urea & 0 & 0 & 0 & 0 & 0 & 0 \\
\hline \multicolumn{7}{|l|}{ Growth in the presence of: } \\
\hline $2 \%$ (wt/vol) $\mathrm{NaCl}$ & 100 & 100 & 0 & 71 & 79 & 100 \\
\hline $5 \%$ (wt/vol) $\mathrm{NaCl}$ & 0 & 0 & 0 & 0 & 0 & 0 \\
\hline \multicolumn{7}{|l|}{ Growth at: } \\
\hline pH 5.5 & 100 & 0 & 0 & 0 & 14 & 0 \\
\hline pH 9.0 & 100 & 0 & 0 & 36 & 21 & 0 \\
\hline $15^{\circ} \mathrm{C}$ & 0 & 0 & 100 & 79 & 36 & 0 \\
\hline $50^{\circ} \mathrm{C}$ & 100 & 100 & 0 & 0 & 79 & 100 \\
\hline \multicolumn{7}{|l|}{ Acid produced from: } \\
\hline D-Glucose & 0 & 0 & 100 & 93 & 100 & 100 \\
\hline L-Arabinose & 0 & 0 & 0 & 0 & 0 & 0 \\
\hline D-Fructose & 100 & 100 & 50 & 86 & 0 & 100 \\
\hline D-Galactose & 0 & 0 & 0 & 29 & 0 & 100 \\
\hline Maltose & 0 & 0 & 0 & 79 & 93 & 100 \\
\hline Lactose & 0 & 0 & 0 & 0 & 0 & 0 \\
\hline Sucrose & 0 & 0 & 0 & 64 & 29 & 0 \\
\hline D-Xylose & 0 & 0 & 0 & 0 & 0 & 0 \\
\hline Trehalose & 0 & 0 & 50 & 86 & 100 & 50 \\
\hline Glycerol & 100 & 0 & 0 & 93 & 93 & 100 \\
\hline D-Mannitol & 0 & 0 & 50 & 100 & 100 & 100 \\
\hline Starch & 0 & 0 & 0 & 0 & 0 & 0 \\
\hline \multicolumn{7}{|l|}{ Gas produced from: } \\
\hline D-Glucose & 0 & 0 & 0 & 0 & 0 & 0 \\
\hline L-Arabinose & 0 & 0 & 0 & 0 & 0 & 0 \\
\hline D-Xylose & 0 & 0 & 0 & 0 & 0 & 0 \\
\hline D-Mannitol & 0 & 0 & 0 & 0 & 0 & 0 \\
\hline Fermentation of glucose & 0 & 0 & 0 & 0 & 0 & 0 \\
\hline Litmus reduction & 0 & 0 & 0 & 7 & 7 & 0 \\
\hline \multicolumn{7}{|l|}{ Resistance to: } \\
\hline Ampicillin $(10 \mu \mathrm{g} / \mathrm{ml})$ & 0 & 0 & 50 & 100 & 7 & 0 \\
\hline Chloramphenicol $(10 \mu \mathrm{g} / \mathrm{ml})$ & 0 & 0 & 100 & 86 & 0 & 0 \\
\hline Neomycin $(50 \mu \mathrm{g} / \mathrm{ml})$ & 100 & 100 & 0 & 93 & 36 & 50 \\
\hline Erythromycin $(20 \mu \mathrm{g} / \mathrm{ml})$ & 0 & 0 & 0 & 7 & 0 & 0 \\
\hline Tetracycline $(30 \mu \mathrm{g} / \mathrm{ml})$ & 100 & 0 & 0 & 0 & 0 & 0 \\
\hline Gramicidin $(50 \mu \mathrm{g} / \mathrm{ml})$ & 100 & 100 & 100 & 100 & 93 & 100 \\
\hline \multicolumn{7}{|l|}{ Growth inhibition of: } \\
\hline E. coli & 0 & 0 & 0 & 14 & 79 & 50 \\
\hline B. subtilis & 100 & 100 & 0 & 71 & 81 & 50 \\
\hline$S$ layer protein & 0 & 100 & 100 & 100 & 100 & 100 \\
\hline
\end{tabular}

${ }^{a} n$ is the number of strains studied.

${ }_{b}^{b}$ Percentage of positive strains. 


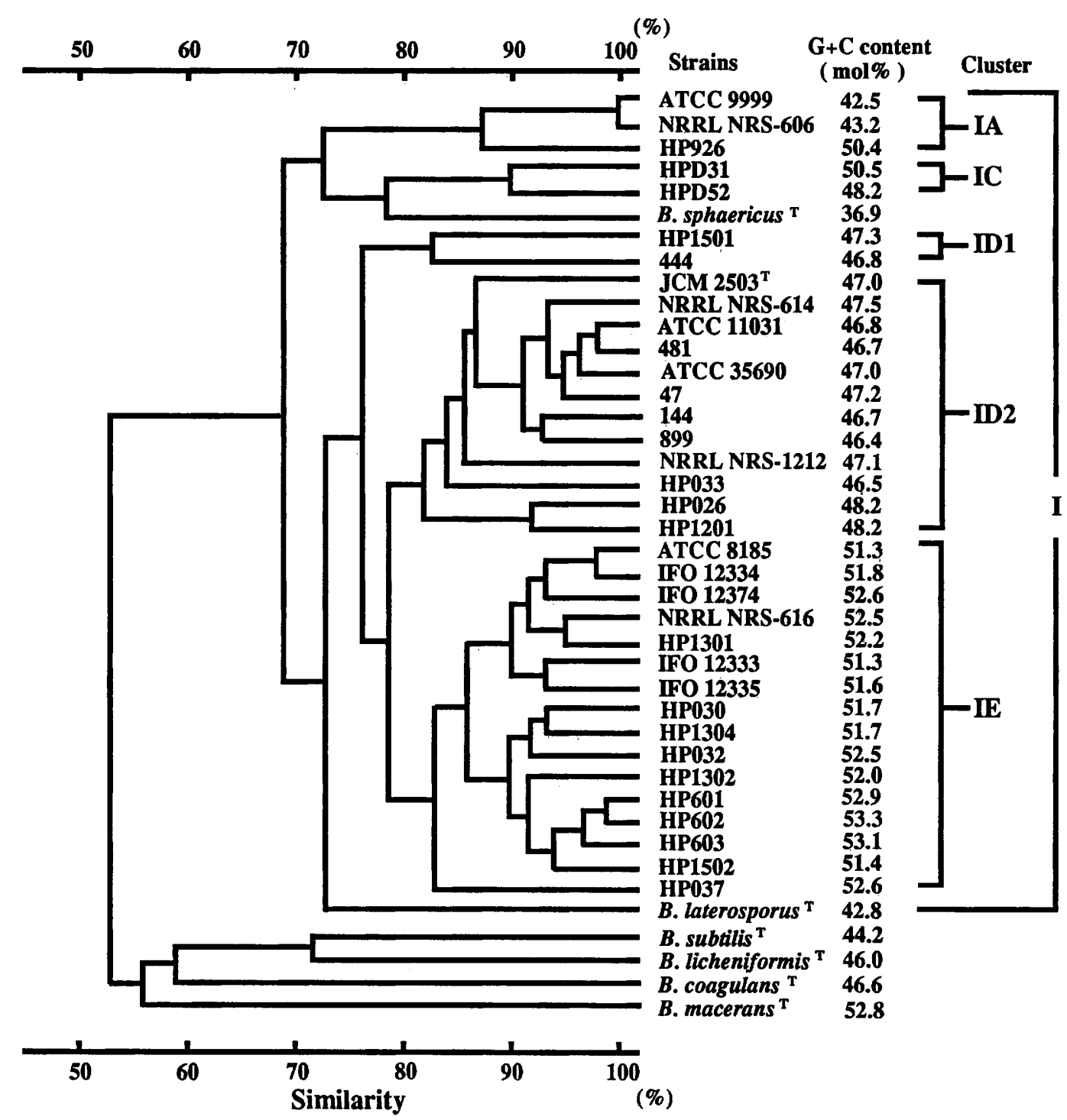

FIG. 1. Dendrogram showing the phenotypic relationships among the strains studied, as determined by using the simple matching coefficient, the unweighted pair group arithmetic average algorithm, and 57 characteristics.

cient, and clustering was based on the unweighted pair group arithmetic average algorithm (34). Computation was carried out by using the NTSYS-pc program of Rohlf (28).

DNA-DNA hybridization. DNA-DNA hybridization was carried out by using photobiotin (Vectra Laboratories, Inc., Burlingame, Calif.) labeling probes in microplate wells as described by Ezaki et al. (6). The templates and biotinylated probe DNAs were used at levels of $1.0 \mu \mathrm{g}$ per well and $20 \mathrm{ng}$ per well, respectively. Hybridization was performed at $37^{\circ} \mathrm{C}$ for $12 \mathrm{~h}$. The DNA reassociation ratios were determined by using streptoavidin-peroxidase (Zymed Laboratory, Inc., San Francisco, Calif.) and 3,3',5,5'-tetramethylbenzidine (Dojin Kagaku, Kumamoto, Japan) (12) and were estimated with a microplate reader at $620 \mathrm{~nm}$. DNA from $E$. coli (type VIII; Sigma Chemical Co., St. Louis, Mo.) was used as the negative control.

Cellular fatty acid composition. Cells cultivated overnight in T2 medium at 30 or $37^{\circ} \mathrm{C}$ were used for cellular fatty acid analysis. Cellular fatty acid composition was determined by the method described by Suzuki and Komagata (36).
Quinone composition. Cells cultivated overnight in $\mathrm{T} 2$ medium at 30 or $37^{\circ} \mathrm{C}$ were used to determine quinone composition by the method described by Komagata and Suzuki (15).

Immunological analysis. Extracellular proteins were prepared as reported previously $(5,24)$. The $7.5 \%$ sodium dodecyl sulfate (SDS)-polyacrylamide gel electrophoresis was carried out as described by Laemmli (16). Western blot (immunoblot) analysis of the extracellular proteins was performed as described by Towbin et al. (41). Rabbit antisera to the middle cell wall protein (protein MWP) of strain 47 and to the cell wall protein (protein HWP) of strain HPD31 were prepared as reported previously $(24,43)$.

Southern blot analysis. Southern blot analysis of restriction fragments of chromosomal DNAs was performed as described by Southern (35), and then the enhanced chemiluminescence gene detection system (Amersham International plc, Amersham, United Kingdom) was used according to the manufacturer's protocol. The 1.0-kb $\mathrm{HpaI}-\mathrm{Bg} l \mathrm{II}$ fragment of 


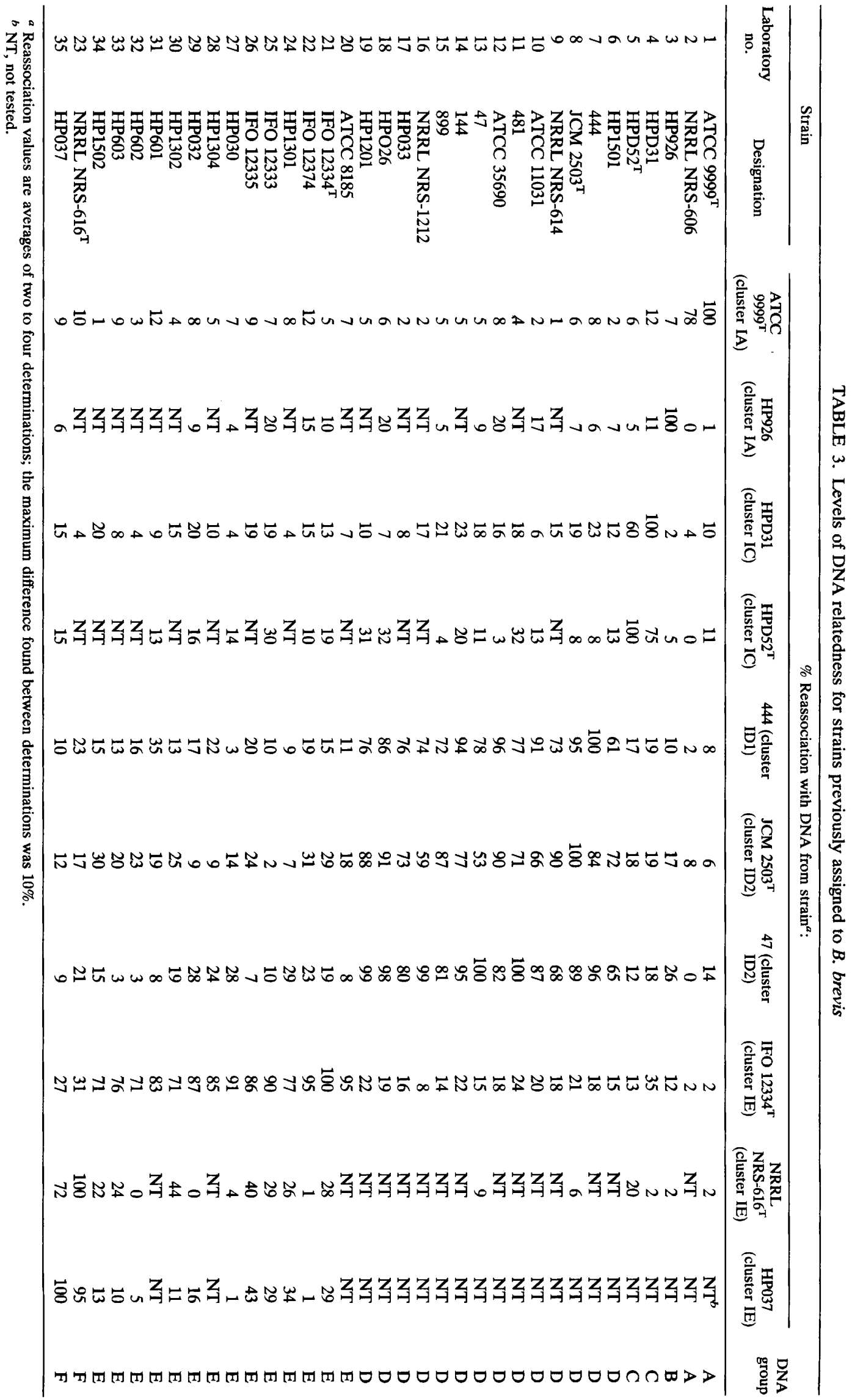


TABLE 4. DNA base compositions and levels of DNA relatedness for selected Bacillus strains

\begin{tabular}{|c|c|c|c|c|c|c|c|}
\hline \multirow[b]{2}{*}{ Strain $^{a}$} & \multirow{2}{*}{$\begin{array}{l}\mathrm{G}+\mathrm{C} \text { content } \\
(\mathrm{mol} \%)\end{array}$} & \multicolumn{6}{|c|}{$\%$ Reassociation with DNA from strain ${ }^{b}$ : } \\
\hline & & $\begin{array}{l}\text { ATCC } \\
9999^{\mathrm{T}}\end{array}$ & HP926 & 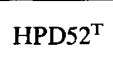 & JCM $2503^{\mathrm{T}}$ & IFO $12334^{T}$ & $\begin{array}{c}\text { NRRL } \\
{\text { NRS- } 616^{T}}^{T}\end{array}$ \\
\hline B. subtilis JCM $1465^{\mathrm{T}}$ & 44.2 & 14 & 3 & 3 & 1 & 5 & 4 \\
\hline B. sphaericus $\mathrm{JCM} 2502^{\mathrm{T}}$ & 36.9 & 8 & 1 & 8 & 9 & 1 & 4 \\
\hline B. laterosporus JCM $2496^{\mathrm{T}}$ & 42.8 & 21 & 2 & 16 & 6 & 19 & 15 \\
\hline B. licheniformis $\mathrm{JCM} 2505^{\mathrm{T}}$ & 46.0 & 5 & 3 & 2 & 4 & 10 & 0 \\
\hline B. coagulans JCM $2257^{\mathrm{T}}$ & 46.6 & 7 & 1 & 8 & 4 & 10 & 3 \\
\hline B. macerans $\mathrm{JCM} 2500^{\mathrm{T}}$ & 52.8 & 22 & 1 & 0 & 1 & 9 & 3 \\
\hline “B. aneurinolyticus" ATCC 12856 & 42.9 & 38 & 22 & 0 & 13 & 0 & 8 \\
\hline "B. aneurinolyticus" ATCC 11376 & 42.9 & 44 & 19 & 25 & 20 & 2 & 25 \\
\hline B. alvei IFO $3343^{\mathrm{T}}$ & 45.4 & 12 & 24 & 15 & 0 & 16 & 18 \\
\hline B. badius ATCC $14574^{\mathrm{T}}$ & 43.5 & 11 & 18 & 21 & 25 & 13 & 21 \\
\hline “B. freudenreichii” ATCC 7053 & 41.8 & 6 & 27 & 4 & 11 & 3 & 0 \\
\hline B. thiaminolyticus JCM 7538 & 53.0 & 5 & 20 & 19 & 17 & 13 & 47 \\
\hline B. thiaminolyticus JCM 7539 & 43.0 & 32 & 42 & 10 & 24 & 16 & 22 \\
\hline B. thiaminolyticus JCM 7540 & 52.5 & 2 & 16 & 8 & 1 & 6 & 4 \\
\hline B. thiaminolyticus JCM $8360^{\mathrm{T}}$ & 53.3 & 0 & 12 & 0 & 26 & 1 & 2 \\
\hline
\end{tabular}

${ }^{a}$ Names in quotation marks are not on the Approved Lists of Bacterial Names (32) or in the Index of the Bacterial and Yeast Nomenclatural Changes (20) and had not been validly published as of 1 April 1992.

${ }^{b}$ Reassociation values are averages of two determinations; the maximum difference found between determinations was $10 \%$.

$\phi$-SK10 (5) containing the HWP gene of HPD31 was used as the hybridization probe.

\section{RESULTS}

Phenotypic characterization and numerical analysis. The 14 $B$. brevis strains and 21 protein producers had phenotypic characteristics that were consistent with the standard description of $B$. brevis given by Gordon et al. (10) and Claus and Berkeley (3). These 35 strains were recovered in one cluster (numerical cluster I) at a similarity level of approximately $70 \%$, and five clusters (numerical clusters IA, IC, ID1, ID2, and IE) were recovered at similarity levels of more than $80 \%$ (Fig. 1). Bacillus sphaericus JCM $2502^{\mathrm{T}}$ and Bacillus laterosporus JCM $2496^{\mathrm{T}}$ were included in numerical cluster I in a broad sense, and $B$. subtilis JCM $1465^{\mathrm{T}}$, Bacillus licheniformis JCM $2505^{\mathrm{T}}$, Bacillus coagulans JCM $2257^{\mathrm{T}}$, and Bacillus macerans $\mathrm{JCM} 2500^{\mathrm{T}}$ exhibited distant relationships to $B$. brevis.

DNA base compositions. The DNA base compositions of the 35 strains ranged from 42.5 to $53.3 \mathrm{~mol} \% \mathrm{G}+\mathrm{C}$ (Fig. 1).

DNA-DNA hybridization. Ten strains belonging to numerical clusters IA to IE were selected for DNA probes. The 35 strains belonging to numerical cluster I were separated into six DNA relatedness groups (DNA groups) (Table 3). These groups correlated well with the clusters obtained by numerical analysis. DNA groups A and B included two strains and one strain belonging to numerical cluster IA, respectively. DNA group $C$ was recovered in numerical cluster IC. DNA group D was recovered in numerical clusters ID1 and ID2, which contained the type strain of $B$. brevis. DNA groups $\mathrm{E}$ and $F$ included 14 and 2 strains, respectively, of numerical cluster IE. The $\mathrm{G}+\mathrm{C}$ contents for each group varied by no more than 2 mol\%. Reference strains of known Bacillus species showed low levels of relatedness with the DNAs from six strains belonging to numerical cluster I (Table 4).

Fatty acid composition and quinone system. Fatty acid compositions and quinone systems were analyzed for the following strains: ATCC 9999 ${ }^{\mathrm{T}}$, HP926, HPD52 ${ }^{\mathrm{T}}$, HPD31, $B$. brevis JCM $2503^{\mathrm{T}}$, IFO $12334^{\mathrm{T}}$, and NRRL NRS-616 ${ }^{\mathrm{T}}$. Strains HP926, HPD52, HPD31, B. brevis JCM 2503 ${ }^{\mathrm{T}}$, IFO $12334^{\mathrm{T}}$, and NRRL NRS-616 ${ }^{\mathrm{T}}$ contained large amounts of anteiso- $\mathrm{C}_{15: 0}$ acid (30 to $60 \%$ of the total fatty acids) and iso- $C_{15: 0}$ acid (30 to $60 \%$ ); in contrast, strain ATCC $9999^{\mathrm{T}}$ contained large amounts of iso- $\mathrm{C}_{15: 0}$ acid (45\%), $\mathrm{C}_{16: 0}$ acid $(20 \%)$, and iso- $\mathrm{C}_{15: 0}$ acid $(5 \%)$. All strains tested had menaquinone 7 (more than $90 \%$ of the total menaquinones).

Analysis of cell wall protein. All strains identified as $B$. brevis (laboratory no. 1 through 35 [Table 1]) accumulated one or two major high-molecular-weight proteins in the culture fluid (Fig. 2A). The approximate molecular weights of the cell wall proteins observed in strains HPD31 (laboratory no. 4), HPD52 ${ }^{\mathrm{T}}$ (laboratory no. 5), 47 (laboratory no. 13), and HP033 (laboratory no. 17) are reported to be $135 \times$ $10^{3}$ (strain HPD31), $115 \times 10^{3}$ (strain HPD52 ${ }^{\mathrm{T}}$ ), $150 \times 10^{3}$ and $130 \times 10^{3}$ (strain 47 ), and $150 \times 10^{3}$ and $110 \times 10^{3}$ (strain HP033) $(5,11,24,43)$. The immunological relationships between the extracellular proteins and the cell wall protein (HWP) of strain HPD31 are shown in Fig. 2B. The antiserum against HWP cross-reacted with the extracellular proteins produced by most of the strains belonging to numerical cluster I; the exceptions were the proteins of members of DNA group A (ATCC $9999^{\mathrm{T}}$ [laboratory no. 1] and NRRL NRS-606 [laboratory no. 2]) and B. sphaericus JCM $2502^{\mathrm{T}}$ (laboratory no. 37). The cross-reactions of the proteins with the antiserum against MWP of strain 47 were the same as those with the antibody against HWP (data not shown).

The results of hybridization between the HWP gene probe and restricted chromosomal DNAs coincided with the results of Western blot analysis and DNA relatedness studies (Fig. 3); namely, the probe hybridized with the DNA fragments of the strains belonging to numerical cluster I except the members of DNA groups A and B. sphaericus JCM $2502^{\mathrm{T}}$ under stringent conditions. Therefore, these positive strains contained a sequence very similar to that of the HWP gene of strain HPD31. Moreover, the Southern blot profiles correlated well with the DNA groups.

\section{DISCUSSION}

The 35 strains assigned to $B$. brevis in numerical cluster I would be identified broadly as $B$. brevis according to phenetic classification, but on the basis of numerical data, DNA base composition, and DNA relatedness they should be 


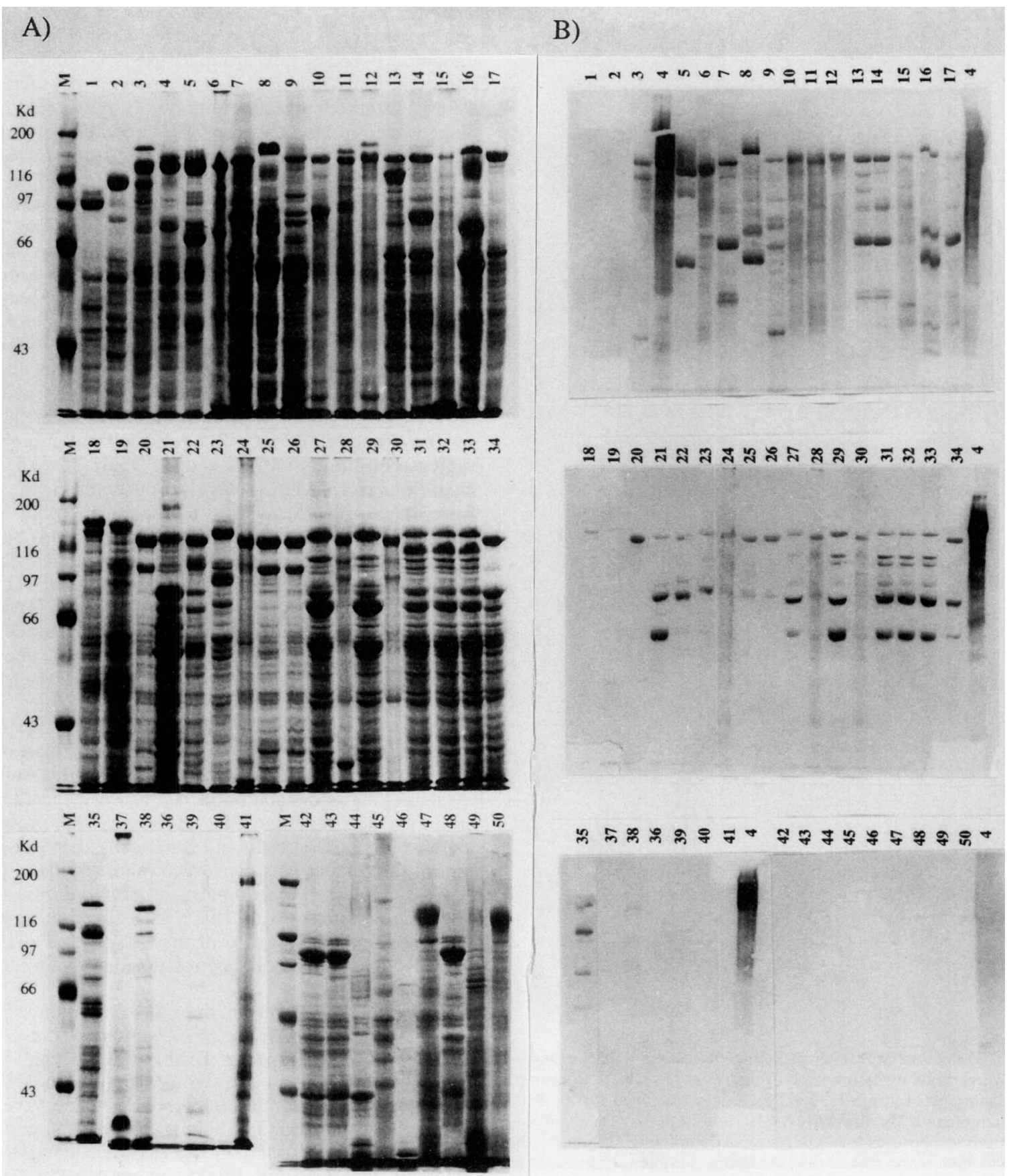

FIG. 2. Detection of S layer proteins of various Bacillus strains by Western blot analysis. (A) 7.5\% SDS-polyacrylamide Coomassiestained gel of extracellular proteins. (B) Western blot analysis of various strains. A $7.5 \%$ SDS-polyacrylamide gel was transferred electrophoretically to nitrocellulose sheets. Immunoreactive protein bands containing antiserum against the cell wall protein (HWP) of strain HPD31 were detected with an Immunostaining HRP Kit (Konica Co., Tokyo, Japan). The lane numbers are the laboratory numbers of the strains (Table 1). Lane $\mathbf{M}$ contained marker protein. $\mathrm{Kd}$, kilodaltons.

separated into six independent species, which we designated species A through F. These species are consistent with the proposal of De Ley (4) that the $\mathrm{G}+\mathrm{C}$ contents of members of a species should not differ by more than about \pm 1 mol\%. Species D included the type strain of $B$. brevis; hence, it represented $B$. brevis sensu stricto. Only $40 \%$ of the strains were correctly identified as $B$. brevis. Furthermore, species $B$ through $F$ have similar cellular fatty acid compositions, and they all have a conserved specific surface layer protein. Species A clearly differs from species B through F.

B. sphaericus was allied with species A through C (Fig. 1). However, characteristics such as the form of sporangia with round spores, growth in $5 \% \mathrm{NaCl}$, a $\mathrm{G}+\mathrm{C}$ content of 36.9 mol\% (this study), and low levels of DNA relatedness (1 to $8 \%$ ) (Table 4) differentiate B. sphaericus from species A through $C$. The known strictly aerobic and oval-spore- 


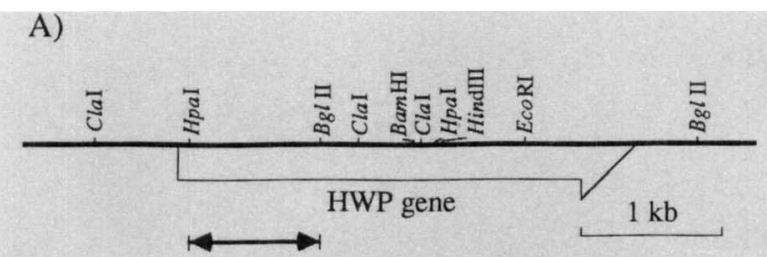

B)

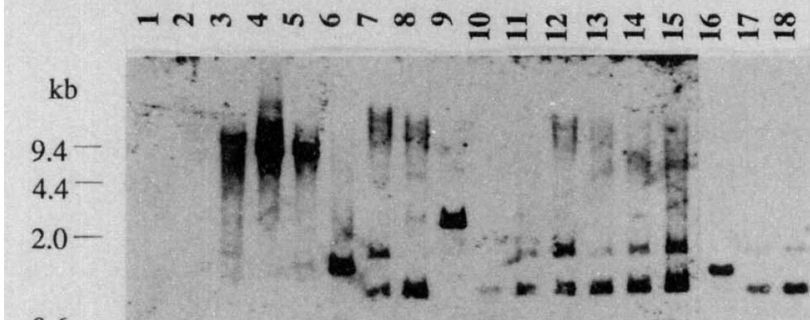

0.6
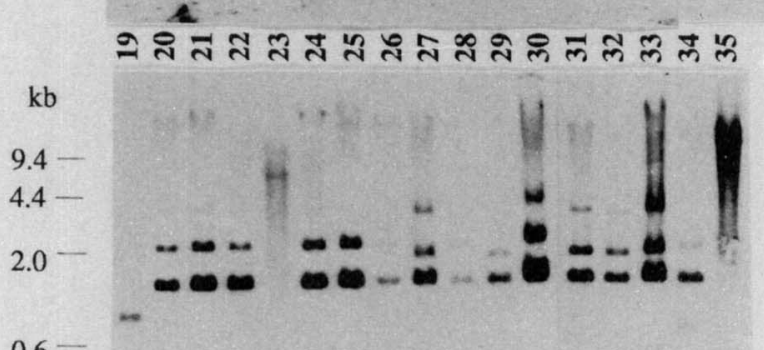

กิ $\mathrm{kb}$

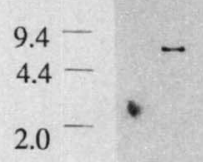

0.6

FIG. 3. Detection of $\mathbf{S}$ layer protein genelike sequences of various Bacillus strains by Southern blot analysis. (A) Restriction map of the HWP gene of strain HPD31 (5). The probe used for hybridization is indicated by the arrow. (B) Southern blot analysis of various strains. Chromosomal DNAs were completely digested with $E c o$ RI. The lane numbers are the laboratory numbers of the strains (Table 1). Fragment sizes are indicated on the left.

forming Bacillus species with $\mathrm{G}+\mathrm{C}$ contents of 42 to 54 mol\% include $B$. subtilis, Bacillus pumilus, Bacillus atrophaeus, Bacillus badius, Bacillus firmus, Bacillus alginolyticus, Bacillus chondroitinus, Bacillus amyloliquefaciens, Bacillus halophilus, and Bacillus stearothermophilus (Table 5). These known species are genetically and phenotypically distinct from species A through $F$, as shown in Tables 4 and 5. These results indicate that there is no relationship between the six independent species (species A through F) and the above-mentioned established species.

Therefore, we propose for species A, C, E, and F the following names: Bacillus migulanus sp. nov, Bacillus cho- shinensis sp. nov., Bacillus parabrevis sp. nov., and Bacillus galactophilus sp. nov., respectively. Species B was left unnamed because this group consists of only one strain. Although the combination of phenotypic characteristics in Table 2 rather clearly differentiated $B$. brevis and the newly named species, evaluation of $\mathrm{G}+\mathrm{C}$ contents and extent of DNA-DNA hybridization were highly useful for confirming the identification of these organisms.

Crystalline protein surface layers have been found in 19 members of the genus Bacillus (33), including "Bacillus aneurinolyticus" (1), B. brevis, B. sphaericus (47), B. licheniformis (40), B. stearothermophilus (19), and Bacillus thuringiensis (18). The cell wall structures of $B$. brevis 47 and HP033 (identified in this study) and $B$. choshinensis HPD31 and HPD52 (identified in this study) are quite different from those of most gram-positive bacteria. The cell walls of these organisms consist of a peptidoglycan layer and two cell wall protein layers (outer wall and middle wall) in the case of strains 47 and HP033 $(10,43)$ or one cell wall protein layer in the case of strains HPD31 and HPD52 ${ }^{\mathbf{T}}$ (11). The cell wall layers (surface layers [S layers]) observed in these strains have a hexagonal array with lattice constants of 14.5 to 18 $\mathrm{nm}(11,42,48)$. The S-layer proteins of strains 47 and HPD31 are composed of proteins with approximate molecular weights of $130 \times 10^{3}$ (outer wall protein) and $150 \times 10^{3}$ (MWP) (strain 47) $(24,43)$ and $135 \times 10^{3}$ (HWP) (strain HPD31) $(5,11)$. The deduced amino acid sequence obtained from the nucleotide sequence of the HWP gene shows a high level of homology (78\%) with the sequence of the MWP gene (5).

Therefore, an interesting question is how the taxonomic properties of protein-secreting bacteria correlate with their cell wall morphology. On the basis of the limited data available, many eubacterial $S$ layers were considered to be strain-specific features (33). However, the present study showed immunologically and genetically that a specific protein of the $\mathrm{S}$ layer was conserved in all strains of $B$. brevis, B. choshinensis, B. parabrevis, B. galactophilus, species B, and $B$. laterosporus JCM $2496^{\mathrm{T}}$. This observation elucidates the taxonomic significance of the $S$ layer and suggests that there is a close evolutionary relationship among the abovementioned species.

Although they differ in their $\mathrm{G}+\mathrm{C}$ contents and DNA relatedness, $B$. brevis, $B$. choshinensis, B. parabrevis, $B$. galactophilus, and species $B$ have the specific $S$ layer in common; thus, they can be designated the " $B$. brevis group." $B$. brevis and B. laterosporus, which have a similar specific S-layer protein, belong to the same cluster on phylogenetic trees based on 16S rRNA sequences $(2,8,29)$, whereas " $B$. aneurinolyticus," whose $S$ layer differs from that of $B$. brevis immunologically and genetically, forms a separate line of descent different from $B$. brevis $(2,8)$.

The strains of the $B$. brevis group have the following characteristics in common. The cells are rod shaped $(0.5$ to 0.9 by 2 to $4 \mu \mathrm{m}$ ), motile, and peritrichous. Ellipsoidal spores are formed in swollen sporangia. Colonies are flat and smooth on nutrient agar. The maximum growth temperature is 45 to $55^{\circ} \mathrm{C}$. The organisms are positive for catalase activity, development of an alkaline $\mathrm{pH}$ in Voges-Proskauer broth, and the presence of a specific S-layer protein. They are negative for the Voges-Proskauer reaction, anaerobic growth, hydrolysis of starch and urea, utilization of nitrate, growth in the presence of $5 \% \mathrm{NaCl}$ and $30 \mu \mathrm{g}$ of tetracycline per $\mathrm{ml}$, and acid production from L-arabinose, lactose, $\mathrm{D}$-xylose, and starch. The major cellular fatty acids are 
TABLE 5. Characteristics that differentiate B. migulanus, the B. brevis group, and allied Bacillus species ${ }^{a}$

\begin{tabular}{|c|c|c|c|c|c|c|c|}
\hline Taxon & $\begin{array}{c}\text { Swollen } \\
\text { sporangia }\end{array}$ & $\begin{array}{l}\text { Voges- } \\
\text { Proskauer } \\
\text { reaction }\end{array}$ & $\begin{array}{c}\mathrm{pH} \text { in } \\
\text { Voges- } \\
\text { Proskauer } \\
\text { broth }\end{array}$ & $\begin{array}{l}\text { Hydrolysis } \\
\text { of starch }\end{array}$ & $\begin{array}{l}\text { Growth in } \\
\text { the presence } \\
\text { of } 5 \% \mathrm{NaCl}\end{array}$ & $\begin{array}{l}\text { Growth } \\
\text { at } 60^{\circ} \mathrm{C}\end{array}$ & $\begin{array}{c}\mathrm{G}+\mathrm{C} \text { content } \\
(\mathrm{mol} \%)\end{array}$ \\
\hline B. migulanus ${ }^{b}$ & $+^{c}$ & - & $>7.0$ & - & - & - & 43 \\
\hline B. brevis group ${ }^{b}$ & + & - & $>7.0$ & - & - & - & $47-53$ \\
\hline B. subtilis ${ }^{d}$ & - & + & V & + & + & - & $34-48$ \\
\hline B. pumilus ${ }^{d}$ & - & + & $<6.0$ & - & + & - & $33-45$ \\
\hline B. atrophaeus ${ }^{e}$ & + & + & $<6.0$ & + & + & - & $41-43$ \\
\hline B. badius ${ }^{d}$ & + & - & $>7.0$ & - & + & - & $44-50$ \\
\hline B. firmus ${ }^{d}$ & + & - & 6 to 7 & _ & + & - & $41-47$ \\
\hline B. alginolyticus $f$ & + & - & $>7.0$ & + & - & - & $47-49$ \\
\hline B. chondroitinus ${ }^{f}$ & + & - & $>7.0$ & + & - & - & $47-48$ \\
\hline B. amyloliquefaciens ${ }^{g}$ & - & + & NT & + & + & - & $44-46$ \\
\hline B. halophilus & - & - & NT & - & + & - & 52 \\
\hline B. stearothermophilus ${ }^{d}$ & + & - & $<6.0$ & + & $\mathrm{V}$ & + & $44-52$ \\
\hline
\end{tabular}

${ }^{a}$ Strictly aerobic, oval-spore-forming species with $\mathrm{G}+\mathrm{C}$ contents of 42 to $54 \mathrm{~mol} \%$.

${ }^{b}$ Data from this study.

$c+$, positive; - , negative; V, variable; NT, not tested.

${ }^{d}$ Physiological data from reference $3 ; \mathrm{G}+\mathrm{C}$ content data from reference 7 .

- Data from reference 22

$f$ Data from reference 21 .

$g$ Data from reference 25 .

${ }^{h}$ Data from reference 46.

anteiso- $\mathrm{C}_{15: 0}$ and iso- $\mathrm{C}_{15: 0}$ acids. The quinone is menaquinone 7.

Description of Bacillus migulanus sp. nov. Bacillus migulanus (mi.gu.la'nus. M.L. adj. migulanus, referring to the German bacteriologist W. Migula, who contributed to bacterial taxonomy). Cells are rod shaped ( 0.5 to 1.0 by 2 to 6 $\mu \mathrm{m})$. Gram positive. Motile and peritrichous. Ellipsoidal spores are formed in swollen sporangia. Colonies are flat, smooth, and pale yellow on nutrient agar. Growth occurs at temperatures ranging from 20 to $50^{\circ} \mathrm{C}$. Grows at $\mathrm{pH} 5.5$ to 9.0. Positive for catalase, oxidase, reduction of nitrate to nitrite, development of an alkaline $\mathrm{pH}$ in Voges-Proskauer broth, hydrolysis of DNA, utilization of ammonium, acid production from $\mathrm{D}$-fructose and glycerol, and growth in the presence of $2 \% \mathrm{NaCl}$ and $30 \mu \mathrm{g}$ of tetracycline per $\mathrm{ml}$. Negative for the Voges-Proskauer reaction; anaerobic growth; alkaline digestion of litmus milk; hydrolysis of casein, gelatin, starch, Tween 60, Tween 80, and urea; utilization of citrate and nitrate; growth in the presence of $5 \% \mathrm{NaCl}$; acid production from $\mathrm{D}$-glucose, L-arabinose, D-galactose, maltose, lactose, sucrose, D-xylose, trehalose, D-mannitol, and starch; and the presence of a specific $\mathrm{S}$-layer protein. The major cellular fatty acid components are iso- $C_{15: 0}$ and $C_{16: 0}$ acids. The quinone is menaquinone 7 . The $\mathrm{G}+\mathrm{C}$ content ranges from 42.5 to $43.2 \mathrm{~mol} \%$; the $\mathrm{G}+\mathrm{C}$ content of the type strain is $42.5 \mathrm{~mol} \%$. The type strain is ATCC 9999 (= JCM 8504), which was isolated as a gramicidin producer.

Description of Bacillus choshinensis sp. nov. Bacillus choshinensis (cho.shi.nen'sis. M.L. adj. choshinensis, referring to Choshi, a city in Japan, where the organism was isolated). Strains of this species have the common characteristics of the $B$. brevis group. In addition, positive for oxidase, utilization of citrate and ammonium, and acid production from D-glucose. Negative for reduction of nitrate to nitrite; hydrolysis of casein, gelatin, Tween 60 , and Tween 80; growth in the presence of $2 \% \mathrm{NaCl}$, at $50^{\circ} \mathrm{C}$, and at $\mathrm{pH} 5.5$ and 9.0; acid production from $\mathrm{D}$-galactose, maltose, sucrose, and glycerol; and alkaline digestion of litmus milk. The $\mathrm{G}+\mathrm{C}$ content ranges from 48.2 to $50.5 \mathrm{~mol} \%$; the $\mathrm{G}+\mathrm{C}$ content of the type strain is $48.2 \mathrm{~mol} \%$. Two strains were isolated from soils in Choshi, Chiba, Japan, as protein producers. The type strain is HPD52. Strain HPD52 ${ }^{\mathrm{t}}$ has been deposited in the Japan Collection of Microorganisms as strain JCM $8505^{\mathrm{T}}$.

Description of Bacillus parabrevis sp. nov. Bacillus parabrevis (pa.ra.bre'vis. Gr. prep. para, alongside of, like; M. L. adj. brevis, short; M. L. parabrevis, brevis-like, referring to $B$. brevis). Strains of this species have the common characteristics of the $B$. brevis group. In addition, positive for reduction of nitrate to nitrite; utilization of ammonium; hydrolysis of casein, gelatin, DNA, and Tween 60; and acid production from D-glucose, trehalose, and D-mannitol. Negative for acid production from $\mathrm{D}$-fructose and $\mathrm{D}$-galactose. The $\mathrm{G}+\mathrm{C}$ content ranges from 51.3 to $53.3 \mathrm{~mol} \%$; the $\mathrm{G}+\mathrm{C}$ content of the type strain is $51.8 \mathrm{~mol} \%$. The type strain is IFO 12334 (= ATCC 10027 = JCM 8506).

Description of Bacillus galactophilus sp. nov. Bacillus galactophilus (ga.lac.to.phi'lus. Gr. n galacto, milk, referring to galactose; Gr. adj. philus, loving; M. L. galactophilus, galactose loving). In addition to the common characteristics of the $B$. brevis group, strains of $B$. galactophilus are positive for utilization of ammonium; hydrolysis of casein, gelatin, DNA, Tween 60, and Tween 80; growth in the presence of $2 \% \mathrm{NaCl}$ and at $50^{\circ} \mathrm{C}$; and acid production from D-glucose, D-fructose, D-galactose, glycerol, and D-mannitol. Negative for reduction of nitrate to nitrite; growth at $\mathrm{pH}$ 5.5 and 9.0; and alkaline digestion of litmus milk. The $\mathrm{G}+\mathrm{C}$ content ranges from 52.5 to $52.6 \mathrm{~mol} \%$; the $\mathrm{G}+\mathrm{C}$ content of the type strain is $52.5 \mathrm{~mol} \%$. The type strain is NRRL NRS-616 (= JCM 8507).

\section{ACKNOWLEDGMENTS}

We thank K. Suzuki of the Japan Collection of Microorganisms, Riken, for helpful discussions and kind suggestions concerning analysis of fatty acid compositions and quinone systems, T. Ezaki of Gifu University for kind suggestions concerning DNA-DNA hybridization, L. K. Nakamura of the National Center for Agricultural Utilization Research, ARS, USDA, for reading the manuscript and useful comments, and $\mathrm{H}$. Yamazaki and Y. Sakaguchi for technical assistance. We also thank the National Center for Agricultural Utilization Research, ARS, USDA, for supplying cultures. 


\section{REFERENCES}

1. Abe, M., and N. Kimoto. 1984. Distribution of two types of regular-array particles in the cell wall of Bacillus aneurinolyticus (Kimura et Aoyama). Microbiol. Immunol. 28:841-846.

2. Ash, C., J. A. E. Farrow, S. Wallbanks, and M. D. Collins. 1991. Phylogenetic heterogeneity of the genus Bacillus revealed by comparative analysis of small-subunit-ribosomal RNA sequences. Lett. Appl. Microbiol. 13:202-206.

3. Claus, D., and R. C. W. Berkeley. 1986. Genus Bacillus Cohn 1872 , p. $1105-1139$. In P. H. A. Sneath, N. S. Mair, M. E. Sharpe, and J. G. Holt (ed.), Bergey's manual of systematic bacteriology, vol. 2. The Williams \& Wilkins Co., Baltimore.

4. De Ley, J. 1978. Modern molecular methods in bacterial taxonomy: evolution, application, prospects, p. 347-357. In Proceedings of the Fourth International Conference on Plant Pathology and Bacteriology, vol. 1. Gilbert-Clarey, Tours, France.

5. Ebisu, S., A. Tsuboi, H. Takagi, Y. Naruse, H. Yamagata, N. Tsukagoshi, and S. Udaka. 1990. Conserved structures of cell wall protein genes among protein-producing Bacillus brevis strains. J. Bacteriol. 172:1312-1320.

6. Ezaki, T., Y. Hashimoto, and E. Yabuuchi. 1989. Fluorometric deoxyribonucleic acid-deoxyribonucleic acid hybridization in microdilution wells as an alternative to membrane filter hybridization in which radioisotopes are used to determine genetic relatedness among bacterial strains. Int. J. Syst. Bacteriol. 39:224-229.

7. Fahmy, F., J. Flossdorf, and D. Claus. 1985. The DNA base composition of the type strains of the genus Bacillus. Syst. Appl. Microbiol. 6:60-95.

8. Farrow, J. A. E., C. Ash, S. Wallbanks, and M. D. Collins. 1992. Phylogenetic analysis of the genera Planococcus, Marinococcus and Sporosarcina and their relationships to members of the genus Bacillus. FEMS Microbiol. Lett. 93:167-172.

9. Gause, G. F., and M. G. Brazhnikova. 1944. Gramicidin S. Origin and mode of action. Lancet ii:715-716.

1.0. Gordon, R. E., W. C. Haynes, and C. H. Pang. 1973. The genus Bacillus. Agriculture Handbook no. 427. U.S. Department of Agriculture, Washington, D.C.

11. Gruber, K., H. Tanahashi, A. Tsuboi, N. Tsukagoshi, and S. Udaka. 1988. Comparative study on the cell wall structure of protein-producing Bacillus brevis. FEMS Microbiol. Lett. 56: $113-118$.

12. Hara, T., T. Shimoda, K. Nonaka, and S. Ogata. 1991. Colorimetric detection of DNA-DNA hybridization microdilution wells for taxonomic application on bacterial strains. J. Ferment. Bioeng. 72:122-124.

13. Kämpfer, P. 1991. Application of miniaturized physiological tests in numerical classification and identification of some bacilli. J. Gen. Appl. Microbiol. 37:225-247.

14. Komagata, K. 1985. Bacteria (1)-the aerobic bacteria, p. 99-161. In T. Hasegawa (ed.), Classification and identification of microorganisms, vol. 2. Gakkai Schuppan, Tokyo. (In Japanese.)

15. Komagata, K., and K. Suzuki. 1987. Lipid and cell-wall analysis in bacterial systematics. Methods Microbiol. 19:161-207.

16. Laemmli, U. K. 1970. Cleavage of structural proteins during the assembly of the head of bacteriophage T4. Nature (London) 227:680-685.

17. Logan, N. A., and R. C. W. Berkeley. 1981. Classification and identification of members of the genus Bacillus using API tests, p. 106-140. In R. C. W. Berkley and M. Goodfellow (ed.), The aerobic endospore-forming bacteria: classification and identification. Academic Press, London.

18. Luckevich, M. D., and T. J. Beveridge. 1989. Characterization of a dynamic $S$ layer on Bacillus thuringiensis. J. Bacteriol. 171:6656-6667.

19. Messner, P., F. Hollaus, and U. B. Sleytr. 1984. Paracrystalline cell wall surface layers of different Bacillus stearothermophilus strains. Int. J. Syst. Bacteriol. 34:202-210.

20. Moore, W. E. C., and L. V. H. Moore. 1989. Index of the bacterial and yeast nomenclatural changes. American Society for Microbiology, Washington, D.C.

21. Nakamura, L. K. 1987. Bacillus alginolyticus sp. nov. and
Bacillus chondoroitinus sp. nov., two alginate-degrading species. Int. J. Syst. Bacteriol. 37:284-286.

22. Nakamura, L. K. 1989. Taxonomic relationship of black-pigmented Bacillus subtilis strains and a proposal for Bacillus atrophaeus sp. nov. Int. J. Syst. Bacteriol. 39:295-300.

23. Nakamura, L. K. 1991. Bacillus brevis Migula 1900 taxonomy: reassociation and base composition of DNA. Int. J. Syst. Bacteriol. 41:510-515.

24. Ohmizu, H., T. Sasaki, N. Tsukagoshi, S. Udaka, N. Kaneda, and K. Yagi. 1983. Major proteins released by a proteinproducing bacterium, Bacillus brevis 47 , are derived from cell wall protein. J. Biochem. 94:1077-1084.

25. Priest, F. G., M. Goodfellow, L. A. Shute, and R. C. W. Berkeley. 1987. Bacillus amyloliquefaciens sp. nov., nom. rev. Int. J. Syst. Bacteriol. 37:69-71.

26. Priest, F. G., M. Goodfellow, and C. Todd. 1981. The genus Bacillus: a numerical analysis, p. 91-103. In R. C. W. Berkley and $\mathrm{M}$. Goodfellow (ed.), The aerobic endospore-forming bacteria: classification and identification. Academic Press, London.

27. Priest, F. G., M. Goodfellow, and C. Todd. 1988. A numerical classification of the genus Bacillus. J. Gen. Microbiol. 134:18471882.

28. Rohlf, F. J. 1989. NTSYS-pc. Numerical taxonomy and multivariate analysis system, version 1.50. Exeter Publishing, Ltd., New York.

29. Rössler, D., W. Ludwig, K. H. Schleifer, C. Lin, T. J. McGill, J. D. Wisotzkey, P. Jurtshuk, Jr., and G. E. Fox. 1991. Phylogenetic diversity in the genus Bacillus as seen by $16 \mathrm{~S}$ rRNA sequencing studies. Syst. Appl. Microbiol. 14:266-269.

30. Saito, H., and K. Miura. 1963. Preparation of transforming deoxyribonucleic acid by phenol treatment. Biochim. Biophys. Acta 72:619-629.

31. Singer, S., K. A. Doherty, and A. D. Stambaugh. 1988. Abstr. Annu. Meet. Am. Soc. Microbiol. 1988, D34, p. 76.

32. Skerman, V. B. D., V. McGowan, and P. H. A. Sneath. 1989. Approved lists of bacterial names, amended edition. American Society for Microbiology, Washington, D.C.

33. Sleytr, U. B., and P. Messner. 1988. Crystalline surface layers in procaryotes. J. Bacteriol. 170:2891-2897.

34. Sneath, P. H. A., and R. R. Sokal. 1973. The principles and practice of numerical classification. W. H. Freeman and Co., San Francisco.

35. Southern, E. 1979. Gel electrophoresis of restriction fragments. Methods Enzymol. 68:152-176.

36. Suzuki, K., and K. Komagata. 1983. Taxonomic significance of cellular fatty acid composition in some coryneform bacteria. Int. J. Syst. Bacteriol. 33:188-200.

37. Takagi, H., K. Kadowaki, and S. Udaka. 1989. Screening and characterization of protein-hyperproducing bacteria without detectable exoprotease activity. Agric. Biol. Chem. 53:691-699.

38. Takagi, H., A. Miyauchi, K. Kadowaki, and S. Udaka. 1989. Potential use of Bacillus brevis HPD31 for the production of foreign proteins. Agric. Biol. Chem. 53:2279-2280.

39. Tamaoka, J., and K. Komagata. 1984. Determination of DNA base composition by reversed-phase high performance liquid chromatography. FEMS Microbiol. Lett. 25:125-128.

40. Tang, M., K. Owens, R. Pietri, X. Zhu, R. McVeigh, and B. K. Ghosh. 1989. Cloning of the crystalline cell wall protein gene of Bacillus licheniformis NK 105. J. Bacteriol. 171:6637-6648.

41. Towbin, H., T. Staehlin, and J. Gordon. 1979. Electrophoretic transfer of proteins from polyacrylamide gels to nitrocellulose sheets: producer and some applications. Proc. Natl. Acad. Sci. USA 76: $4350-4354$.

42. Tsuboi, A., H. Engelhardt, U. Santarius, N. Tsukagoshi, S. Udaka, and W. Baumeister. 1989. Three-dimensional structure of the surface protein layer (MW layer) of Bacillus brevis 47. J. Ultrastruct. Mol. Struct. Res. 102:178-187.

43. Tsuboi, A., N. Tsukagoshi, and S. Udaka. 1982. Reassembly in vitro of hexagonal surface arrays in a protein-producing bacterium, Bacillus brevis 47. J. Bacteriol. 151:1485-1497.

44. Udaka, S. 1976. Screening for protein-producing bacteria. Agric. Biol. Chem. 40:523-528.

45. Udaka, S., N. Tsukagoshi, and H. Yamagata. 1989. Bacillus 
brevis, a host bacterium for efficient extracellular production of useful proteins. Biotechnol. Genet. Eng. Rev. 7:113-146.

46. Ventosa, A., M. T. García, M. Kamekura, H. Ohnishi, and F. Ruiz-Berraquero. 1989. Bacillus halophilus sp. nov., a moderately halophilic Bacillus species. Syst. Appl. Microbiol. 12:162166.

47. Word, N. S., A. A. Yousten, and L. Howard. 1983. Regularly structured and non-regularly structured surface layers of Bacillus sphaericus. FEMS Microbiol. Lett. 17:277-282.
48. Yamada, H., N. Tsukagoshi, and S. Udaka. 1981. Morphological alterations of cell wall concomitant with protein release in a protein-producing bacterium, Bacillus brevis 47. J. Bacteriol. 148:322-332.

49. Yamagata, H., K. Nakahama, Y. Suzuki, A. Kakinuma, N. Tsukagosh, and S. Udaka. 1989. Use of Bacillus brevis for efficient synthesis and secretion of human epidermal growth factor. Proc. Natl. Acad. Sci. USA 86:3589-3593. 